\title{
Profesionalización, vocación y ética de enfermería
}

\section{Professionalism, dedication and motivation, and ethics in nursing}

$\mathrm{L}$ a profesionalización, en enfermería, es un proceso social complejo; proviene del latín professio; significa profesar, es decir, ejercer una ciencia o un arte de forma voluntaria; se refiere también a una ideología o actividad asociada que se encuentra en diversos grupos de profesionales en los que sus integrantes aspiran a un estatus social. El estatus facilita el desarrollo, el crecimiento y la evolución de la profesión, consolidando el concepto de profesionalización o de ocupación, según cada contexto. El crecimiento de la enfermería, en este proceso, presenta factores económicos, políticos y culturales, en los que existe un nivel de crecimiento de acuerdo a criterios generales como el estatus, la vocación y la ética de cada profesional de enfermería.

La vocación es la suma de cualidades que caracteriza a cada persona y la lleva a orientarse hacia un determinado oficio o profesión; en enfermería, los profesionales que acceden a estos estudios por vocación sienten la necesidad de ayudar a los demás, sobre todo en los momentos más difíciles de la vida, cuando la persona se enferma, se siente desvalida y vulnerable. La vocación en enfermería refleja la personalidad de la profesión en cada uno de quienes la ejercen; viene inmersa en los valores y principios de cada uno; es un reflejo del cuidado que demuestra el profesional de enfermería. Para los enfermos, el contar con una mano solidaria, empática y con agradable relación humana, de respeto y cuidado personalizado, es vital y papel de la enfermería, profesión que se debe ejercer con espíritu de servicio, buscando la excelencia en el cuidado y favoreciendo así la calidad en la atención. Se debe estar convencido, primero, de la nobleza de ejercer el "cuidado" como el objeto de estudio, enfrentando siempre nuevos retos. La vocación no debe admitir nunca la rutina en la tarea diaria ni que hayan días iguales en el quehacer asistencial, docente o de investigación; cada día debe ser único a través del reflejo de los valores profesionales e institucionales, así como éticos.

El profesional de la salud debe poseer ética; este término proviene del vocablo griego ethos y significa carácter o modo de ser en los problemas fundamentales de la salud; la conducta humana es la base que relaciona a cada persona sobre la cual, de manera individual o colectiva, deciden que ciertas acciones son correctas o incorrectas; la ética estudia también sus efectos y el valor de dichas acciones; por lo tanto, es una ciencia normativa que se ocupa de un ideal, al poseer virtudes, situación que caracteriza a la enfermería por el compromiso de servicio, y no solamente por la obligación de llevarlo a cabo. La dedicación y el amor hacia nuestra profesión los ejerce cada uno; ésta es la visión que debe tener cada profesionista en su practica diaria y cumplirla con la más alta calidad.

Ma. Guadalupe Nava Galán 